International Journal of Economics, Business and Accounting Research (IJEBAR)

Peer Reviewed - International Journal

Vol-4, Issue-3, 2020 (IJEBAR)

E-ISSN: 2614-1280 P-ISSN 2622-4771

https://jurnal.stie-aas.ac.id/index.php/IJEBAR

\title{
FINDING WAYS TO GROWING SMEs in WEST JAVA
}

\author{
Iqbal Arraniri ${ }^{1}$, Oding Syafrudin ${ }^{2}$, Heni Susilawati ${ }^{3}$ \\ ${ }_{1,2,3}$ Universitas Kuningan, Kuningan \\ Email:iqbal@uniku.ac.id
}

\begin{abstract}
:
The number of micro, small and medium enterprises (SMEs) in 2019, recorded 42 million business units. Thus the majority of our economic actors are small and medium enterprises. In addition, this sector also absorbs 79 million people from the 100 million Indonesian workforce. Therefore, it is necessary to make various efforts to develop small businesses in Indonesia, so that this sector develops better. SMEs that are able to survive for a long time are industries that are able to anticipate changes in every era. Those who are able to withstand the conditions of the times are those who are able to adapt to changes and are able to build networks. Every UKM has a goal to achieve growth and survival for the long term. In the current era of globalization, where competition between companies is getting tighter. SMEs are required to have the ability to develop strategic choices in the field of marketing management so that they are able to adapt to the adaptability of a dynamic business environment. Seeing this fact, the company must be managed with systematic and dynamic efforts to benefit from the ever-changing market developments. For this study, the population used was 157 batik business owners in Cirebon Regency. The sampling technique used in this study was a nonprobability technique, non-probability sampling by means of a census. With this method, researchers used the entire population as the sample because the population was relatively small for the size in the SEM model.
\end{abstract}

Keywords : $\quad$ Entrepreneurial Orientation, Adaptability of The Business Environment, Quality of Business Strategy, Competitive Advantage, SMEs Performance, SEM

\section{Introduction}

Studies of micro, small and medium enterprises (SMEs) always attract attention. Its existence is often associated with community-run businesses with limited expertise and traditional technology. However, the crisis that has befallen Indonesia has raised awareness that in the national economy the small business sector has a very important role in strengthening the structure of the national economy. The importance of the position of the small business sector is not only to strengthen the national industry, but also relates to the lives of most Indonesians. The growth of SMEs requires good performance from the entrepreneurs who with an entrepreneurial spirit make small and medium enterprises dynamic in facing the adaptability of their business environment. The essence of entrepreneurship is creativity and innovation (Gunawan et al., 2013) and has the ability (Freilling et al., 2014) includes the ability to 
International Journal of Economics, Business and Accounting Research (IJEBAR)

Peer Reviewed - International Journal

Vol-4, Issue-3, 2020 (IJEBAR)

E-ISSN: 2614-1280 P-ISSN 2622-4771

https://jurnal.stie-aas.ac.id/index.php/IJEBAR

formulate business goals, motivate oneself, take initiative, habits to create, the ability to mobilize funds, manage time, mental abilities , can take lessons from his experience.

The problems in this study are supported by the gap phenomenon, where there is a decrease in the number of sales in April 2019 to October 2019, which indicates that there is a low business performance, there is a decrease in the number of sales in April 2019 to October 2019, this indicates the existence of low business performance. The problem in this study is also supported by a research gap (1) the entrepreneurial orientation perspective is stated to have a positive effect on competitive advantage by Aloulou, (2002), but stated that it has a negative effect on competitive advantage (Mahfooz et al., 2000); (2) the adaptability of the business environment is stated to have a positive effect on competitive advantage by Utsch et al., (1999), but stated that it has a negative effect on competitive advantage (Chandler and Hanks, 1994); (3) the quality of business strategy is stated to have a positive effect on competitive advantage by Utsch et al., (1999), but stated that it has a negative effect on competitive advantage (Chandler and Hanks, 1994); and (4) competitive advantage is stated to have a positive effect on business performance by Dess, et al., (1996), but stated that it has a negative effect on business performance (Kickul and Gundry, 2002)

\section{Literature Review}

\section{Entrepreneurial Orientation Perspective}

The focus of studies in the field of entrepreneurship has subsequently increased on testing entrepreneurship from an organizational perspective (Suhartini, 2007). Entrepreneurship from an organizational viewpoint is consistent with the view of Canovas et al., (2014) which argues that entrepreneurship will ultimately be dominated by companies that are able to provide more resources for innovation. Shumpeter provides several interesting reasons why companies can increase their entrepreneurial activity. Canovas et al., (2014) explain that an entrepreneur can create big profits. The more entrepreneurs who innovate, the better the economy as a whole will be.

\section{Business Environment Adaptability}

Adaptability of the business environment as a vehicle that provides resources (Freilling et al., 2014). In terms of measuring and operationalizing the adaptability of the external business environment, so far there have been two approaches, namely objective environment measures and subjective (perceptual environment measures). Subjective measurement based on the manager's attention and interpretation of the adaptability of the company's external business environment. However, whatever approach is used, the element of relevance is more important. Based on the foregoing, in this study the adaptability of the external business environment is measured based on the perceptions and interpretations of company leaders (Canovas et al., 2014).

\section{Quality of business strategy}

Tunggal (2004) explains that business strategy is a strategy that must be used as the main thinking base in making an information technology strategy because the strategy states the company's vision and mission along with the performance targets of each function and organizational structure. According to Hamel in Rangkuti (2002), strategy is a tool to achieve company goals in relation to long-term goals, follow-up programs, and resource allocation priorities.

Giglierano noted that the effective business strategy in small companies depends on the type of business and the product being developed. Giglierano in Hanifah (2011) found that certain SME business strategies were adopted to achieve better performance. Forrest in Hanifah (2011) observes that small companies must develop new strategies to react to changes in the 
International Journal of Economics, Business and Accounting Research (IJEBAR)

Peer Reviewed - International Journal

Vol-4, Issue-3, 2020 (IJEBAR)

E-ISSN: 2614-1280 P-ISSN 2622-4771

https://jurnal.stie-aas.ac.id/index.php/IJEBAR

nature of business as reflected in factors such as increased competition, both national and international, increased internationalization of the market, and new global competitors.

\section{Competitive Advantage}

Kotler and Armstrong (2003) define competitive advantage as an advantage over competitors obtained by offering lower value or by providing greater benefits due to higher prices. Meanwhile, according to Porter (2004) competitive advantage is the heart of company performance in a competitive market, however, after decades of great expansion and prosperity, many companies lose sight of competitive advantage in their struggle to develop more in pursuit of diversification.

\section{Business performance}

Performance measurement is something complex and a big challenge for a researcher. Performance is a big challenge because as a construct, performance is multidimensional so that the use of a single measurement is unable to provide a comprehensive understanding. Performance in the complete Indonesian dictionary (Tim Prima Pena) is something that is achieved or an achievement is shown, so that business performance is something that is achieved or an achievement shown by the company in carrying out its business activities. Barret, et al. (2000, p.52) stated that business performance reflects "how we evaluate our market success".

\section{The Effect of Entrepreneurial Orientation on Competitive Advantage}

The relationship between entrepreneurial orientation and competitive advantage is that entrepreneurial orientation has a positive influence on competitive advantage. The better the consumer's perception of entrepreneurial orientation, the higher the competitive advantage will be. And if consumers' perceptions of entrepreneurial orientation, the competitive advantage will also be lower. Research conducted by Meike Supranoto, (2009) states that entrepreneurial orientation variables have a positive effect on competitive advantage (Empirical study on: Small and Medium Scale Clothing Industry in the city of Semarang). On the basis of the description above, the following hypothesis can be presented:

\section{H1: Entrepreneurial orientation has a positive effect on competitive advantage}

\section{The Effect of Business Environment Adaptability on Competitive Advantage}

Utsch et al., (1999) stated that the adaptability of a conducive business environment related to the socio-economic conditions of society, political climate, competitive conditions and business climate stimulates company managers to improve their entrepreneurial orientation, so that it is concluded that the better the adaptability of the company's business environment, the higher it is. entrepreneurial orientation. So the adaptability of the business environment has a positive effect on competitive advantage.

H2: Adaptation to the Business Environment has a positive effect on competitive advantage

Effect of Quality of Business Strategy on Competitive Advantage

Bloodgood, Sapienza \& Almeida, (1996) explain that the better the quality of marketing the company does is able to provide competitive advantages with other companies. Bloodgood, Sapienza \& Almeida, (1996) show that a quality strategy in terms of marketing products from 
International Journal of Economics, Business and Accounting Research (IJEBAR)

Peer Reviewed - International Journal

Vol-4, Issue-3, 2020 (IJEBAR)

E-ISSN: 2614-1280 P-ISSN 2622-4771

https://jurnal.stie-aas.ac.id/index.php/IJEBAR

one company is able to provide a strategic asset in winning a competitive advantage. So the quality of business strategy has a positive effect on competitive advantage.

H3: The quality of business strategy has a positive effect on competitive advantage

The Influence of Entrepreneurial Orientation on Business Performance

The existence of innovation shows that the company has the enthusiasm to do new things by leaving previous practices in a better direction. Exploration of new ideas and ideas is a form of innovation to create new products so that companies have an advantage in competing. Chresnawan Teddy Prasetyo (2012) also did a significant positive influence between entrepreneurial orientation on business performance. Based on the description above, the following hypothesis can be proposed:

H4: Entrepreneurial orientation has a positive effect on business performance.

The Effect of Business Environment Adaptability on Business Performance

To improve business performance, business actors are required to be able to adapt to the changing patterns of the environment which are always dynamic. Changes that occur include the competencies required by the company, the organizational structure of the business, career paths and changes from externals such as market interest and an uncertain political climate. Pearce and Robinson (2007) explain that the greater the degree of environmental change, a company manager will face fewer alternatives and environmental evaluation criteria.

H5: The adaptability of the business environment has a positive effect on business performance.

\section{The Effect of Business Strategy Quality on Business Performance}

An important factor in business is the implementation of a suitable business strategy so that the company can remain competitive. In the long term, business strategies are often used as the basis for the company to determine steps in order to achieve business goals. In entering the era of intense competition, business players will apply competitive strategies in order to remain competitive. The business strategy that is implemented must be adjusted to the core competencies of the company and the environment around the company. Business strategy is also a path that company organizations will take in carrying out business missions to achieve the company's business vision (Djoko Mulyono, 2012).

H6: The quality of business strategy has a positive effect on business performance.

\section{The Effect of Competitive Advantage on Business Performance}

The relationship between competitive advantage and business performance is that competitive advantage has a positive influence on business performance. The better the consumer's perception of business performance, the higher the competitive advantage will be. And if consumers' perceptions of business performance, the competitive advantage will also be lower. Research conducted by Bagas Prakosa, (2005) states that the variable competitive advantage has a positive effect on company performance (Empirical study on: Manufacturing Industry in Semarang).

H7: Competitive advantage has a positive effect on business performance.

\section{Research Method}

This study uses quantitative data types because the data presented is related to numbers or scoring. The data is then analyzed and processed into statistical analysis to test the hypotheses that explain the relationship between the variables used. The data source used in this study is primary data. According to Sugiyono (2014), research variables are anything in the form of what is determined by researchers to be studied so that information is obtained about it, then conclusions are drawn. The variables of this study are divided into two, namely: 1. Endogenous 
International Journal of Economics, Business and Accounting Research (IJEBAR)

Peer Reviewed - International Journal

Vol-4, Issue-3, 2020 (IJEBAR)

E-ISSN: 2614-1280 P-ISSN 2622-4771

https://jurnal.stie-aas.ac.id/index.php/IJEBAR

Variable (Y) The endogenous variable is a variable that is affected or which is due to the exogenous variables (Sugiyono, 2014). The related variable in this study is Competitive Advantage \& the performance of SME's. 2. Exogenous Variable (X) Exogenous variable or exogenous variable is a variable that will affect the endogenous variable or in other words the exogenous variable is the cause of the formation of the endogeneous variable. The exogenous variables used in this study are Entrepreneurial Orientation Perspective, Business Environment Adaptability, Quality of Business Strategy. The population in this study were all SMEs in West Java. The sample used was Batik SMEs in Cirebon the number of Batik SMEs in Cirebon was 157.

\section{Result and Discussion}

Based on data collected during the study, a questionnaire distributed to respondents was 157 copies. From the results of data processing most female respondents as respondents as many as 83 people.The table below shows a summary of the results of the analysis of existing data,

Figure 1. Research Model

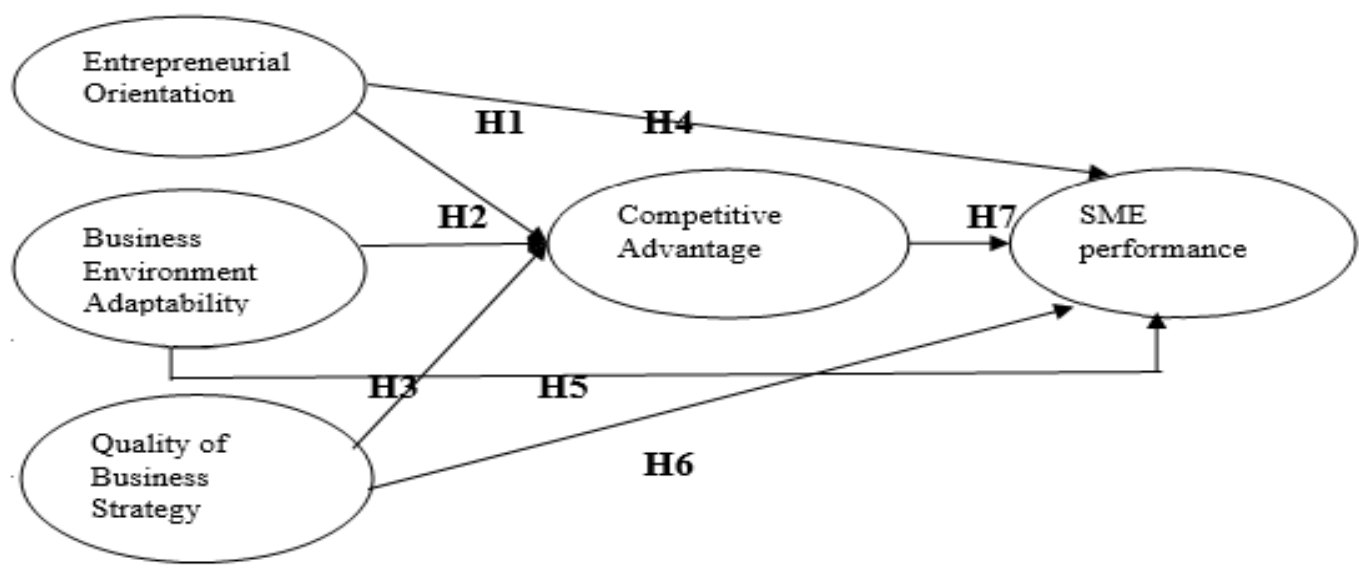

Table1. Sample Characteristics

\begin{tabular}{|c|l|l|l|}
\hline \multicolumn{2}{|l|}{ Demographics Characteristics } & Number Response & of Percent \\
\cline { 2 - 4 } Gender & Male & 74 & 47,13 \\
\cline { 2 - 4 } & Female & 83 & 52,87 \\
\hline
\end{tabular}

Reliability is a measure of the internal consistency of the indicators of a formation variable that shows the degree to which each indicator indicates a generalized variable. There are two ways to test reliability, namely composite / constuct reliability and variance extracted. The cut-off value of constuct reliability is at least 0.70 while the cut-off value for variance extracted is at least 0.50 . The variance extracted shows the amount of variance of the indicators extracted by the developed form variables. The high value of variance extracted indicates that the indicators represent well the variables of the developed form (Ghozali, 2013).

Table 2. Reliability and Variance Extracted Test

\begin{tabular}{|l|l|l|}
\hline \multicolumn{1}{|c|}{ Variable } & Reliability & AVE \\
\hline Entrepreneurial Orientation & 0,883 & 0,654 \\
\hline $\begin{array}{l}\text { Business Environment } \\
\text { Adaptability }\end{array}$ & 0,852 & 0,69 \\
\hline Quality of Business & 0,909 & 0,715 \\
\hline
\end{tabular}


International Journal of Economics, Business and Accounting Research (IJEBAR)

Peer Reviewed - International Journal

Vol-4, Issue-3, 2020 (IJEBAR)

E-ISSN: 2614-1280 P-ISSN 2622-4771

https://jurnal.stie-aas.ac.id/index.php/IJEBAR

\begin{tabular}{|l|l|l|}
\hline Strategy & & \\
\hline Competitive Advantage & 0,91 & 0,67 \\
\hline Performance of SME's & 0,93 & 0,725 \\
\hline
\end{tabular}

The reliability for each construct turned out to be high all values were above the cut of value 0.70 . The results of the variance extracted calculation showed that all constructs met the minimum cut of value requirement of 0.50 .

Table 3. Hypothesis Testing

\begin{tabular}{|l|r|l|r|r|r|r|l|}
\hline \multicolumn{2}{|c|}{ Variable } & estimate & SE & CR & P & Information \\
\hline $\begin{array}{l}\text { Competitive } \\
\text { Advantage }\end{array}$ & $<--$ & Entrepreneurial Orientation &, 250 &, 222 & 1,130 &, 258 & Sig \\
\hline $\begin{array}{l}\text { Competitive } \\
\text { Advantage }\end{array}$ & $<--$ & $\begin{array}{l}\text { Business Environment } \\
\text { Adaptability }\end{array}$ &, 347 &, 126 & 2,745 &, 006 & Sig \\
\hline $\begin{array}{l}\text { Competitive } \\
\text { Advantage }\end{array}$ & $<---$ & Quality of Business Strategy &, 037 &, 088 &, 424 &, 671 & Sig \\
\hline $\begin{array}{l}\text { Performance of } \\
\text { SME's }\end{array}$ & $<--$ & Competitive Advantage &, 297 &, 100 & 2,962 &, 003 & Sig \\
\hline $\begin{array}{l}\text { Performance of } \\
\text { SME's }\end{array}$ & $<--$ & Entrepreneurial Orientation &, 140 &, 201 &, 695 &, 487 & Sig \\
\hline $\begin{array}{l}\text { Performance of } \\
\text { SME's }\end{array}$ & $<--$ & $\begin{array}{l}\text { Business Environment } \\
\text { Adaptability }\end{array}$ &, 326 &, 122 & 2,664 &, 008 & Sig \\
\hline
\end{tabular}

The estimated parameter for testing the effect of entrepreneurial orientation on competitive advantage shows a CR value of 1.130 and a probability of 0.258 . The two values obtained did not meet the requirements for $\mathrm{H} 1$ acceptance, namely the $\mathrm{CR}$ value of 1.130 which was smaller than 1.96 and the probability of 0.258 which was greater than 0.05 . Thus it can be concluded that entrepreneurial orientation has no effect on competitive advantage. The estimation parameter for testing the adaptability of the business environment to competitive advantage shows a CR value of 2.745 and with a probability of 0.006 . The two values obtained meet the requirements for $\mathrm{H} 2$ acceptance, namely the $\mathrm{CR}$ value of 2.745 which is greater than 1.96 and the probability of 0.006 which is smaller than 0.05 . Thus it can be concluded that the adaptability of the business environment has an effect on competitive advantage. The estimation parameter for testing the quality of business strategy on competitive advantage shows the CR value of 0.424 and with a probability of 0.671 . The two values obtained do not meet the requirements for acceptance of $\mathrm{H3}$, namely the $\mathrm{CR}$ value of 0.424 which is smaller than 1.96 and the probability of 0.671 which is greater than 0.05 . Thus it can be concluded that business strategy has a positive effect on competitive advantage. The estimated parameter for testing the effect of competitive advantage on business performance shows a CR value of 2.962 and a probability of 0.003 . The two values obtained meet the requirements for acceptance of $\mathrm{H} 4$, namely the CR value of 2.962 which is greater than 1.96 and a probability of 0.003 which is smaller than 0.05 . Thus, it can be concluded that competitive advantage has a positive effect on business performance.

The estimation parameter for testing the effect of entrepreneurial orientation on business performance shows a CR value of 0.695 and a probability of 0.487 . The two values obtained do not meet the requirements for acceptance of $\mathrm{H} 5$, namely the CR value of 0.695 which is smaller 
International Journal of Economics, Business and Accounting Research (IJEBAR)

Peer Reviewed - International Journal

Vol-4, Issue-3, 2020 (IJEBAR)

E-ISSN: 2614-1280 P-ISSN 2622-4771

https://jurnal.stie-aas.ac.id/index.php/IJEBAR

than 1.96 and the probability of 0.487 which is greater than 0.05 . Thus it can be concluded that entrepreneurial orientation does not have a positive influence on business performance. The estimation parameter for testing the influence of business environment adaptability on business performance shows a CR value of 2.664 and a probability of 0.008 . The two values obtained meet the requirements for acceptance of H6, namely the CR value of 2.664 which is greater than 1.96 and a probability of 0.008 which is smaller than 0.05 . Thus it can be concluded that the adaptability of the business environment has a positive influence on business performance. The estimated parameter for testing the effect of the quality of business strategy on business performance shows a CR value of 1.620 and a probability of 0.105 . The two values obtained do not meet the requirements for acceptance of $\mathrm{H} 7$, namely the $\mathrm{CR}$ value of 1.620 which is smaller than 1.96 and a probability of 0.105 which is greater than 0.05 . Thus it can be concluded that the quality of business strategy does not have a positive effect on business performance

\section{Conclusion}

Batik SMEs in Cirebon City must pay attention to competitive advantages, namely by prioritizing the adaptability of the existing business environment. Business performance will be formed if batik owners are able to see the existing competitive advantages and are able to compete competitively. The limitations of this research modeling are that there are only two hypotheses that are answered and the other two cannot be answered, especially regarding their effect on competitive advantage. The results of this study cannot be generalized to other cases outside the object of this study

\section{References}

Aloulou, W. 2002, "Entrepreneurial Orientation Diagnosis in SMEs : Some Conceptual dan Methodological Dimensions", Entrepreneurship Research in Europe: Specificities dan Perspective, University of Sfacx, Tunisia, pp. 1-27.

Aynur, Akata, dan Ayse Akyol, (2008), "Increasing competitive performance of small and medium sized enterprises: A market orientation approach for success," Harvard Bussiness Review

Bagas prakosa,2010,"PENGARUH ORIENTASI PASAR,ORIENTASI PEMBELAJARAN DAN INOVASI TERHADAP KINERJA PERUSAHAAN UNTUK MENCAPAI KEUNGGULAN BERSAING", Jurnal study manejemen dan organisasi vol 2 nol.

Canovas; Gines Hernandez; M Camino Ramon Llorens; dan Johanna Koeter Kans, (2014), "A demand approach to borrower discouragement," JEL

Cavusgil, S. T. \& S. Zou (1994), "Marketing Strategy Performance Relationship : An Investigation of The Empirical Link in Export Market Ventures", Journal of Marketing, 58 (January), 1-21

Covin, J. G., and Slevin, D. P. 1991, "A Conceptual model of Entrepreneurship as Firm Behavior", Entrepreneurship: Theory and Practice, Vol. 16 (1), pp. 7-24.

Freilling, Jorg; dan Christop Lucke Schelhowe, (2014), "The impact of entrepreneurial orientation on the performance of internationalization, "Entrepreneurship and Performance of Firms

Gunawan, Theresia; Jojo Jacob; dan Geert Duysters, (2013), "Entrepeneurial orientation and network ties," Working Papper

Jap, Sandy D., 1999, "Pie-Expansion Effort : Collaboration Processes in Buyer Supplier Relationship", Journal of Marketing Research, Vol.36, November, p.461-475

Kayed, Rasem N dan M Kabir Hasan, (2010), "Islamic entrepreneurship: a case study of Saudi Arabia," Journal of Developmental Entrepreneurship

Keats, B.W. dan Hitt, M.A (1988) "A Causal Model of Linkages Among Environmental Dimension, Macro Organizational Characteristics and Performance", Academy 
International Journal of Economics, Business and Accounting Research (IJEBAR)

Peer Reviewed - International Journal

Vol-4, Issue-3, 2020 (IJEBAR)

E-ISSN: 2614-1280 P-ISSN 2622-4771

https://jurnal.stie-aas.ac.id/index.php/IJEBAR

of Management Journal, Vol. 31, No. 3, pp.570-598

Kaplan, Robert S. \& David P. Norton (1996), Using The Balanced Scorecard as Strategic Management Sistem, Harvard Business School Press

Lumpkin, GT and Dess, C G (1996). Clarifying the enterpreneural orientation construct and linking it to performance, "Academy of Management Review, vol 21 no 1 p 135 172 ”

Noruzi, Mohammad Reza, (2011), “a quick look on Islamic entrepreneurship,” Interdisciplinary Journal of Contemporary Research in Bussiness

Rafiki, Ahmad; Khalid Mohammed Al Khalifa; dan Imam Buchari, (2014), "Islamic human capital and firm performance," International Journal of Bussiness Management

Suhartini, Karim, (2007), "Analisis pengaruh kewirausahaan korporasi terhadap kinerja perusahaan pada pabrik pengolahan crumb rubber di Palembang," Jurnal Manajemen dan Bisnis Sriwijaya

Supranoto, Meike, 2009, "Strategi Menciptakan Keunggulan Bersaing Produk Melalui Orientasi Pasar, Inovasi, dan Orientasi Kewirausahaan dalam Rangka Meningkatkan Kinerja Pemasaran (Studi Empiris pada Industri Pakaian Jadi Skala Kecil dan Menengah di Kota Semarang)", Tesis, Universitas Diponegoro

Surachman, Nofal Nur; Ubud Salim; dan Djumahir, (2014), "Entrepreneurship orientation, market orientation, business strategy, management capabilities on business performance, " International Journal of Bussiness and Management Invention

Utsch, A., A. Rauch, R. Rothfufs, and M. Frese (1999). "Who beomes a Small Scale Entrepreneur in a Post-Socialist Environment: On the Differences between Entrepreneurs and Managers in East Germany," Journal of Small Business Management 37(3), 31-42.

Weerawardena, Jay, 2003, "Exploring The Role of Market Learning Capability in Competitive Strategy", European Journal of Marketing, Vol. 37

Wiklund, J. 1999, The Sustainability of The Entrepreneurial Orientation-Performance Relationship, Entrepreneurship: Theory and Practice. (Fall), pp. $37-48$. 